\title{
Reptilia, Squamata, Amphisbaenidae, Amphisbaena cegei Montero, 1997, and Reptilia, Squamata, Teiidae, Tupinambis rufescens (Günther, 1871): Vertical range extension
}

\author{
Martin Jansen ${ }^{1,2^{*}}$ and Gunther Köhler ${ }^{1}$ \\ 1 Senckenberg Forschungsinstitut und Naturmuseum. Senckenberganlage 25, 60325. Frankfurt am Main, Germany. \\ 2 Biodiversity and Climate Research Centre (BiK-F). Senckenberganlage 25, 60325. Frankfurt am Main, Germany. \\ * Corresponding autor. E-mail: martin.jansen@gmx.net
}

ABSTRACT: We report on records of Amphisbaena cegei and Tupinambis rufescens in the Bolivian Inter-Andean Dry Forest (Bolivia) that extend the known vertical distribution.

New information on vertical distribution of two reptile species from Bolivia, Amphisbaena cegei Montero, 1997 (Amphisbaenidae) and Tupinambis rufescens (Günther, 1871) (Teiidae), is presented below, in order to improve on the knowledge of the species. The records are based on a short collecting trip from 26 to 28 November 2007 by the authors. Collecting and exportation permits (DGB/ $\mathrm{UVS}^{\circ}{ }^{\circ} 146$ ) were provided by the Ministerio de Desarrollo Sostenible, La Paz, and Servicio Nacional de Sanidad Agropecuaria e Inocuidad Alimentaria (SENASAG). The collected specimens of $A$. cegei and the photograph of $T$. rufescens are deposited in the Museo Noel Kempff Mercado, Santa Cruz, Bolivia (MNKR), and Museum Senckenberg Frankfurt, Germany (SMF).

Collection locality was near Remates (a former finca or small human settlement, now abandoned) (17 $52^{\prime} 48^{\prime \prime}$ S, 6420'36" W, 2116 m, Figure 1), Province of Caballero, Department of Santa Cruz, Bolivia. The locality lies in the ecoregion Inter-Andean Dry Forest according to Ibisch and Mérida (2004).

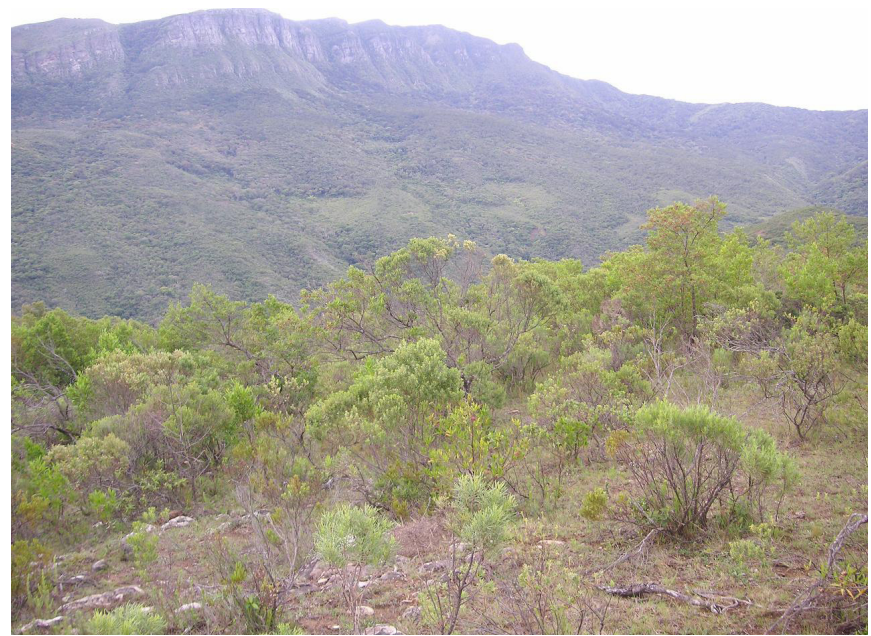

FIGURE 1. Collection locality near Remates $\left(17^{\circ} 52^{\prime} 48^{\prime \prime} \mathrm{S}, 64^{\circ} 20^{\prime} 33^{\prime \prime} \mathrm{W}\right.$, 2,116 m), Province of Caballero, Department of Santa Cruz, Bolivia.
Amphisbaena cegei Montero, 1997 (Figure 2)

Specimens examined: MNKR 4504: 17² $52^{\prime} 48^{\prime \prime}$ S, 6420'33" W, 2,079 m; SMF 86663, SMF 86664: 1753'34" S, 6419'57" W, $2116 \mathrm{~m}$; all specimens collected on 26 November 2007.

Geographic distribution: Bolivia (Department of Santa Cruz). Type locality: Pampagrande (1805'15” S, 6406'51" W), Province of Florida, Department of Santa Cruz, Bolivia. Habitat: Inter-Andean Dry Forest (this study), TucumanBolivian Forest.

Remarks: The record is the highest record of this species and extends the known vertical distribution of this species from 700-1,700 m (C. Börschig, unpublished data) $c a .400 \mathrm{~m}$ to over 2,100 m. Next known locality lies $10 \mathrm{~km}$ southwards in San Juan de Portrero, in ca. 1,600 m (Montero 2001). The specimens were found under rocks in Prepuna-like vegetation.

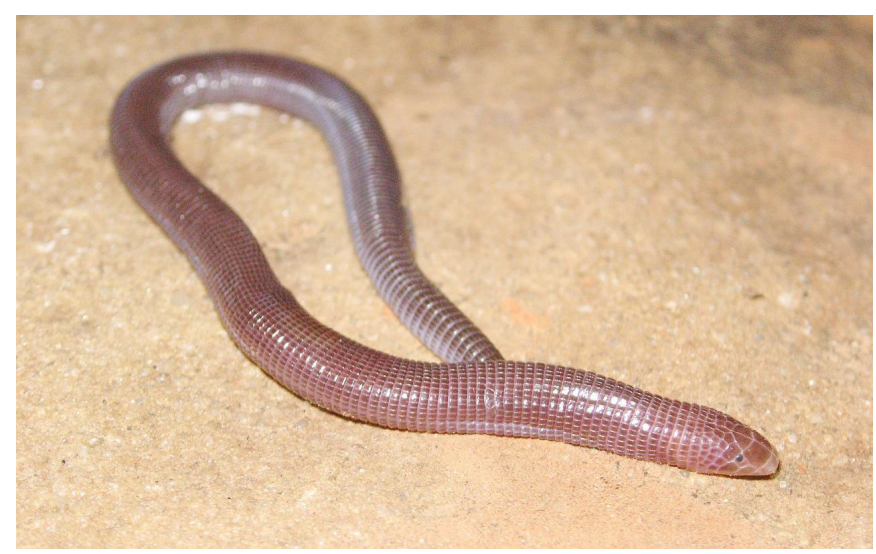

Figure 2. Individual of Amphisbaena cegei (MNKM 4504) from near Remates, Province of Caballero, Department of Santa Cruz, Bolivia.

Tupinambis rufescens (Günther, 1871) (Figure 3)

Photo voucher: SMF-F 237; on the way to Remates

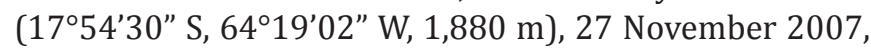
$11: 20 \mathrm{~h}$, sunbathing on the road. 
Geographic distribution: Argentina, Bolivia and Paraguay.

Habitat: Inter-Andean Dry Forest

Remarks: The species is apparently restricted to the Chaco in Argentina, Bolivia and Paraguay (Péres and Colli 2004). It is the northernmost and highest known locality of the species and extends known vertical distribution ca. $500 \mathrm{~m}$. Next known locality lies $30 \mathrm{~km}$ southwest in Pampagrande, in $18^{\circ} 05^{\prime} 17^{\prime \prime} \mathrm{S}, 64^{\circ} 06^{\prime} 59^{\prime \prime} \mathrm{W}$ in $1,311 \mathrm{~m}$ (Gonzales et al. 2004).

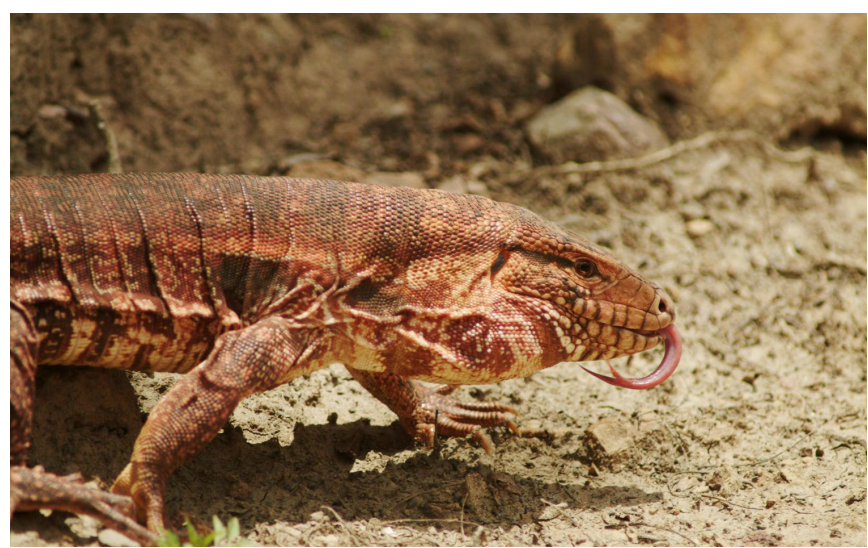

FIGURE 3. Individual of Tupinambis rufescens (photo voucher SMF-F 237) from near Remates, Province of Caballero, Department of Santa Cruz, Bolivia.
ACKNowledgments: Patricia Herrera, Aleida Justiniano, Lucindo Gonzales and Kathia Rivero, Museo Noel Kempff Mercado, Santa Cruz de la Sierra, provided valuable assistance with acquisition of these permits. Ricardo Montero provided valuable comments to a preliminary version of the manuscript. The study was supported by a grant from the "Wilhelm Peters-Fonds" of the Deutsche Gesellschaft für Herpetologie und Terrarienkunde (DGHT) for MJ.

\section{LiTERATURE CITED}

Gonzales, Á.L., D. Embert and R. Montaño. 2004. Reptiles; p. 175-184 In F. Azurduy, H.J.L. Aramayo, B.J. Ledezma and A. Langer (ed.). Historia Natural del Municipio de Pampagrande. Santa Cruz de la Sierra: Museo de Historia Natural Noel Kempff Mercado, U. A. G. R. M.

Ibisch, P.L. and G. Mérida. 2004. Biodiversity: the richness of Bolivia. State of knowledge and conservation. Santa Cruz de la Sierra: Ministry of Sustainable Development. Editorial FAN. 644 p.

Montero, R. 2001. Amphisbaena cegei. Catalogue of American Amphibians and Reptiles 726: 1-3.

Péres, Jr, A.K. and G.R. Colli. 2004. The taxonomic status of Tupinambis rufescens and T. duseni (Squamata: Teiidae), with a redescription of the two species. Occasional Papers of the Sam Noble Oklahoma Museum of Natural History 15: 1-12.

RECEIVED: November 2009

REVISED: August 2010

ACCEPTED: September 2010

PUBLISHED ONLINE: October 2010

EDITORIAL RESPONSIBILITY: Mara Cíntia Kiefer 